\title{
THE EXTRACTION OF QUERCETIN FROM WASTE ONION (Allium Cepa L.) TUNIC BY THE AQUEOUS SOLUTIONS OF DIFFERENT DEEP EUTECTIC SOLVENTS
}

Biljana S. Đorđević*, Zoran B. Todorović, Dragan Z. Troter, Ljiljana P. Stanojević, Vlada B. Veljković

University of Niš, Faculty of Technology, Leskovac, Serbia

In order to find the most efficient natural solvent for the extraction of quercetin, its solubility was tested in the selected deep eutectic solvents (DESs) such as choline chloride:urea (ChCl:U), choline chloride:glycerol (ChCl:G), citric acid:D-glucose (CA:Glc), citric acid:D-fructose (CA:Frc), lecithin:urea (Lec:U) and lecithin:glycerol (Lec:G), as well as in their aqueous solutions, in a temperature range of $6-75^{\circ} \mathrm{C}$. Quercetin was most successfully dissolved in CA:Frc, followed by $\mathrm{ChCl:U}$ and ChCl:G, while CA:Glc was the least efficient. The lecithin-based DESs with urea and glycerol did not dissolve quercetin. The most optimal DES (ChCl:U) was employed in the extraction of quercetin from waste onion (Allium cepa L.) tunic and its efficiency was compared with those of methanol and ethanol. The largest amount of quercetin was extracted with ethanol, followed by methanol and $\mathrm{ChCl:U}$, but quercetin extracted with this DES contained the least amount of impurities. Therefore, the $\mathrm{ChCl}$ U DES was highly recommended for the selective extraction of quercetin.
(ORIGINAL SCIENTIFIC PAPER) UDC 66.061:547.972.3:582.573.16

Keywords: deep eutectic solvent, extraction, quercetin, choline chloride, citric acid, lecithin

\section{Introduction}

Data on the solubility of various organic compounds in different solvents are very important for their use for separation and purification. Unfortunately, the conventional extraction methods are characterized by low selectivity and the presence of the employed extracting solvent in the final product. In most cases, the solvents used for this purpose are water, ethanol or aqueous ethanol solutions, but serious problems that need to be addressed are low efficiency of the extraction because of the variable nature and polarity of extractable bioactive compounds [1]. Various nutritional compounds and pharmaceuticals are obtained by solvent extraction from plant materials. Among these compounds, flavonoids, natural polyphenolic compounds, have been mainly studied. Quercetin (3,3',4',5,7 -pentahydroxyflavanone or 3,3, 4',5,7-pentahydroxy-2-phenylchromen4-one) is a yellow flavonol widely present in plants. It is insoluble in cold water, poorly soluble in hot water, but quite soluble in alcohols and lipids. Some of its beneficial properties include antioxidant, Gastro-protective, antihypertension, in vitro anticancer, antiviral and antibacterial activities, as well as in vivo anti-inflammatory, anxiolytic and antidepressant effects [2]. The solubility of quercetin in aqueous alcohol solutions increased with either heating or increasing mole fractions of alcohols [3]. According to Dong et al. [4], the solubility of quercetin increases with the increase of the molality of cyclodextrins and heating. Chen and Jao [5] improved the solubility of quercetin in water by using phytoglycogen, a carbohydrate polymer extracted from sweet corn.
In recent years, deep eutectic solvents (DESs) have been used in different extraction processes. DESs are usually prepared by combining organic halide salts with a complexing organic agent (usually a hydrogen bond donor) in proper ratios, and are liquid at temperatures below $100{ }^{\circ} \mathrm{C}$ [6]. Beneficial properties of DESs are easy preparation, high purity, low cost, non-volatility at ambient condition, chemical and thermal stability, non-flammability, non-toxicity, biodegradability and good solubility of several organic compounds [7-8]. In addition, DESs produced from exclusively natural products, so-called natural deep eutectic solvents, show the potential to replace conventional organic solvents [9-11]. Choi et al. [12] hypothesized that DESs have a purpose of being a liquid phase for solubilizing, storing, and transporting non-water soluble metabolites in living cells and organisms. Some DESs were used extensively for the extraction of different compounds found in plants [13-17] and animals $[18,19]$. In order to propose a proper DES and to design an optimized production process, it is necessary to know the solubility of quercetin in different DESs.

In the present study, solubility of quercetin in different DESs, namely choline chloride:urea (ChCl:U), choline chloride:glycerol (ChCl:G), citric acid:D-glucose (CA:Glc), citric acid:D-fructose (CA:Frc), lecithin:urea (Lec:U) and lecithin:glycerol (Lec:G) and their aqueous solutions over the temperature range of $6-75^{\circ} \mathrm{C}$ were determined. The most optimal DES was employed in the extraction of quercetin from waste onion (Allium cepa L.) tunic and its efficiency was

\footnotetext{
*Author address: Biljana S. Đorđević, Faculty of Technology, University of Niš,

Bulevar oslobođenja 124, 16000 Leskovac, Serbia

E-mail: djbiljana89@gmail.com

The manuscript received: September,11, 2018.

Paper accepted: October, 30, 2018
} 
compared with those of methanol and ethanol.

\section{Experimental}

\section{Materials}

Choline chloride $(\mathrm{ChCl})$ (Sigma Aldrich, $\geq 98 \%$ ), urea (Zorka, Šabac, Serbia, 99.5\%), glycerol (MeiLab Belgrade, Serbia, Ph Eur grade), citric acid monohydrate (Zorka, Šabac, Serbia, 99.5\%), D-glucose (MosLab, Belgrade, Serbia, 99.0\%), D-fructose (MosLab, Belgrade, Serbia, 99.0\%), lecithin from soybean (Tokyo Chemical Industry, Japan, 99.0\%), methanol (Zorka-Pharma, Šabac, Serbia, 99.5\%) and absolute ethanol (Sigma Aldrich, St. Louis, USA, 99.5\%) were used. Quercetin in a powder form was provided from Merck Chemicals Ltd. (Notingem, United Kingdom). Waste onion tunic was obtained from a local farm near Leskovac (Serbia).

\section{Preparation of DESs}

The selected components for the preparation of DES were mixed in a round-bottomed flask. The flask was then placed on a rotary evaporator at $70^{\circ} \mathrm{C}$ until a homogeneous liquid was formed. DESs were stored in well-closed glass bottles in a desiccator containing $\mathrm{CaCl}_{2}$. The properties of the prepared DESs at room temperature are given in Table 1. The physical and thermodynamic properties of the $\mathrm{ChCl}-$ and citric acid-based DESs can be found elsewhere [6,20].

Table 1. Prepared DESs and their visible properties at room temperature

\begin{tabular}{|c|c|c|c|}
\hline Abbreviation & DES & $\begin{array}{l}\text { Molar ratio } \\
(\mathrm{mol} / \mathrm{mol})\end{array}$ & $\begin{array}{l}\text { Visible properties of DESs at room } \\
\text { temperature }\end{array}$ \\
\hline ChCl:U & Choline chloride:urea & $1: 2$ & $\begin{array}{l}\text { Liquid, viscous, homogeneous, } \\
\text { colorless }\end{array}$ \\
\hline ChCl:G & Choline chloride:glycerol & $1: 2$ & $\begin{array}{l}\text { Liquid, viscous, homogeneous, } \\
\text { colorless }\end{array}$ \\
\hline CA:Glc & Citric acid:D-glucose & $1: 1$ & $\begin{array}{l}\text { Liquid, viscous, homogeneous, } \\
\text { light yellow }\end{array}$ \\
\hline CA:Frc & Citric acid: $D$-fructose & $1: 1$ & $\begin{array}{l}\text { Liquid, viscous, homogeneous, } \\
\text { dark brown }\end{array}$ \\
\hline Lec:U & Lecithin:urea & $1: 2$ & $\begin{array}{l}\text { Liquid, highly viscous, } \\
\text { homogeneous, dark brown }\end{array}$ \\
\hline Lec:G & Lecithin:glycerol & $1: 2$ & $\begin{array}{l}\text { Liquid, highly viscous, } \\
\text { homogeneous, dark brown }\end{array}$ \\
\hline
\end{tabular}

Solubility of quercetin in different aqueous solutions of DESs

Pure DESs and their aqueous solutions at different concentrations of 25,50 and $75 \mathrm{vol} \%$ were used. First, $10 \mathrm{mg}$ of quercetin and $5 \mathrm{ml}$ of the chosen solvent (water, DES or aqueous solution) were placed in a flask equipped with a magnetic stirrer, which was heated in a thermostated chamber at $25^{\circ} \mathrm{C}$ for $1 \mathrm{~h}$. After stirring, the mixture was kept in a refrigerator overnight at $6{ }^{\circ} \mathrm{C}$ in order to establish equilibrium, and the samples from the mixture were taken at $6,25,50$ and $75^{\circ} \mathrm{C}$. Specified temperatures were achieved by heating in a water bath. The solubility of quercetin was determined by HPLC analysis and the concentration of quercetin $(\mathrm{mg} / \mathrm{ml})$ in aqueous solutions DESs was read with a pre-prepared calibration curve for the quercetin standard.

Extraction of quercetin from waste onion (Allium cepa L.) tunic

Dried and powdered onion tunic $(1 \mathrm{~g})$ was combined in the flasks with $10 \mathrm{ml}$ of methanol, ethanol or $\mathrm{ChCl:U}$. After the initial shaking, a sample was taken from the solutions. Then, the flask was placed in a thermostated chamber at $30^{\circ} \mathrm{C}$ and stirred with a magnetic stirrer. The samples were collected at different time intervals $(5 \mathrm{~min}$, $1 \mathrm{~h}, 7 \mathrm{~h}, 19 \mathrm{~h}, 25 \mathrm{~h}, 31 \mathrm{~h}$ and $69 \mathrm{~h}$ ). The concentration of quercetin and quercetin-4'-O-monoglucoside were calculated from corresponding peak areas obtained by HPLC analysis by using calibration curves.

\section{Analytical methods}

The extracts were analyzed by an Agilent 1100 Series chromatograph equipped with a degasser, a binary pump, a thermostated column (Zorbax Eclipse XDB-C18, 4.6 $\times 150 \mathrm{~mm}, 5 \mu \mathrm{m}$ ) and a UV/VIS detector. The samples were dissolved in methanol. All solvents and samples were filtered by a $0.45 \mu \mathrm{m}$ Millipore filter. The volume of the injected sample was $20 \mu \mathrm{l}$. The separation was performed at the $1 \mathrm{ml} / \mathrm{min}$ flow rate of a binary mixture of $1 \%$ aqueous formic acid solution (solvent $A$ ) and methanol (solvent $\mathrm{B}$ ) with a linear gradient of $70 \% \mathrm{~B}$ of 8.5 minutes. The column temperature was $30{ }^{\circ} \mathrm{C}$. The components (quercetin and quercetin-4'-O-monoglucoside) were detected at $370 \mathrm{~nm}$.

\section{Results and discussion}

Solubility of pure quercetin in aqueous solutions of different DESs

Figure 1a-d shows the solubility of quercetin in the choline chloride- and citric acid-based DESs and their aqueous solutions at different temperatures $(6,25,50$ and $75^{\circ} \mathrm{C}$ ). As expected, at all applied temperatures the solubility of quercetin in water was very sparing, close to zero. With ChCl:G, the highest solubility was achieved at the highest temperature (Figure 1a). The solubility of quercetin in the $25 \%$ and $50 \%$ aqueous solutions of $\mathrm{ChCl:G}$ at 6 and $25^{\circ} \mathrm{C}$ was very low at all applied temperatures, but it gradually increased with increasing the amount of the DES, so the solubility of quercetin in the $75 \%$ aqueous solution was $1.0 \mathrm{mg} / \mathrm{ml}$, while the solubility of quercetin in the pure DES was $1.3 \mathrm{mg} / \mathrm{ml}$. However, the solubility of quercetin in the $75 \%$ aqueous solution and in pure $\mathrm{ChCl}: \mathrm{G}$ at $25{ }^{\circ} \mathrm{C}$ increased abruptly, reaching the value of 2.0 and $2.7 \mathrm{mg} / \mathrm{ml}$, respectively. The solubility of quercetin at 25 and $50{ }^{\circ} \mathrm{C}$ was similar. When the $50 \%$ and $75 \%$ aqueous solutions of $\mathrm{ChCl:G}$ were used, the solubility was only slightly higher at $50^{\circ} \mathrm{C}$, while the solubility of quercetin in the pure DES at 25 and $50{ }^{\circ} \mathrm{C}$ was the same. The solubility of quercetin in the $50 \%$ and $75 \%$ aqueous $\mathrm{ChCl:G}$ solutions at $75^{\circ} \mathrm{C}$ was 0.6 and $2.6 \mathrm{mg} / \mathrm{ml}$, respectively. In the pure $\mathrm{ChCl}: \mathrm{G}$, the solubility of quercetin had the maximum value of $2.8 \mathrm{mg} / \mathrm{ml}$. When 
the quercetin solubility in the aqueous $\mathrm{ChCl} U \mathrm{U}$ solutions was tested (Figure 1b), the results differed from those achieved with $\mathrm{ChCl:G}$, but the maximum solubility of quercetin was similar in both solutions. At $6{ }^{\circ} \mathrm{C}$, $\mathrm{ChCl}: \mathrm{U}$ was very viscous, so the measurement of solubility was impossible. At 25,50 and $75^{\circ} \mathrm{C}$, the solubility of quercetin was approximately almost the same for all aqueous solutions of $\mathrm{ChCl}: U$. However, only when the $50 \%$ solution of $\mathrm{ChCl}: \mathrm{U}$ was employed, a difference in the solubility of quercetin was noticed. At 25 and $75^{\circ} \mathrm{C}$, the solubility of quercetin in all aqueous solutions of $\mathrm{ChCl:U}$ was 0.1 and $0.6 \mathrm{mg} / \mathrm{ml}$, respectively. In the $75 \%$ aqueous solutions of $\mathrm{ChCl}: \mathrm{U}$, the solubility of quercetin was in the range from 1.9 to $2.1 \mathrm{mg} / \mathrm{ml}$ for all investigated temperatures.

The solubility of quercetin in pure $\mathrm{ChCl}: \mathrm{U}$ at 25,50 and $75{ }^{\circ} \mathrm{C}$ was in the range from 2.5 to $2.7 \mathrm{mg} / \mathrm{ml}$. Since the solubility was almost the same for the temperature range of $25-75^{\circ} \mathrm{C}$, it could be concluded that in the case of $\mathrm{ChCl}: \mathrm{U}$, the solubility of quercetin rose with heating up to $25{ }^{\circ} \mathrm{C}$, but further heating had no impact on the solubility.
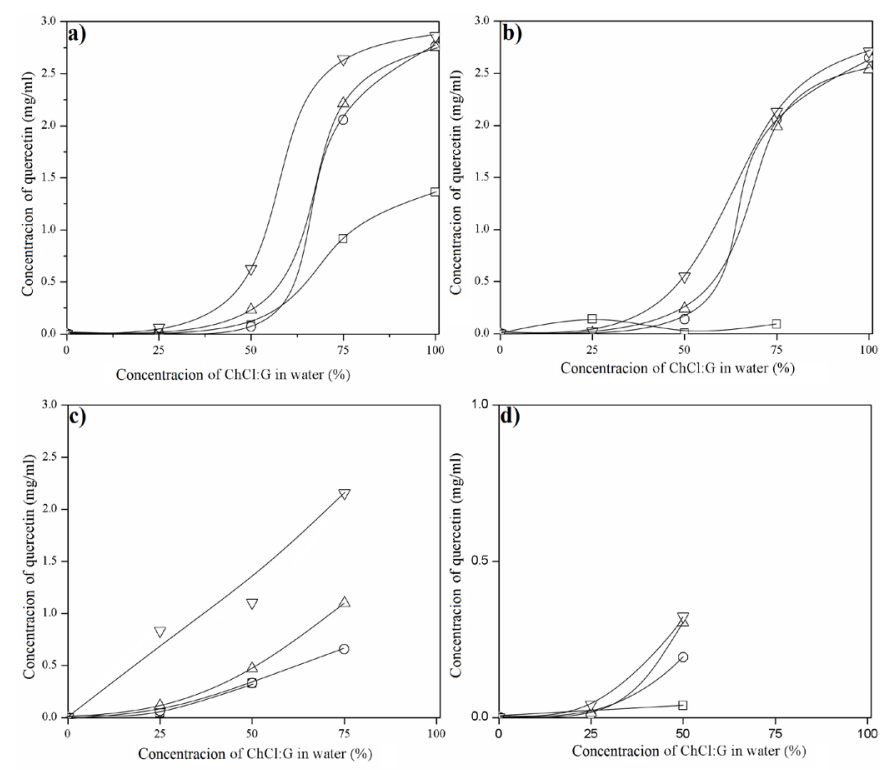

Figure 1. The concentration of quercetin extracted by aqueous solutions of ChCl:G (a), ChCl:U (b), CA:Frc (c) and CA:Glc (d) as a function of the concentration of DES in water (\%) at different temperatures $\left(6{ }^{\circ} \mathrm{C}-\square, 25^{\circ} \mathrm{C}-\circ, 50{ }^{\circ} \mathrm{C}-\triangle\right.$ and $\left.75^{\circ} \mathrm{C}-\nabla\right)$

The determination of the solubility of quercetin in the pure citric-acid based DESs was impossible due to their high viscosity even at $75^{\circ} \mathrm{C}$, so the solubility of quercetin in CA:Frc and CA:Glc DESs was determined only in their aqueous solutions up to $75 \%$ and $50 \%$, respectively (Figure 1c-d). The solubility of quercetin in the CA:Frc aqueous solutions was approximately the same for the temperature range of $6-25^{\circ} \mathrm{C}$. With increasing the amount of DES, the solubility of quercetin also increased. When the $75 \%$ solution was used, the solubility of quercetin in the citric-acid based DESs at $25{ }^{\circ} \mathrm{C}$ reached the value of $0.6 \mathrm{mg} / \mathrm{ml}$. When the 25 and $50 \%$ solutions were used, the solubility of quercetin in the citric-acid based DESs was almost the same at $50^{\circ} \mathrm{C}$. The solubility of quercetin in the aqueous solution of CA:Frc at $75{ }^{\circ} \mathrm{C}$ increased almost linearly with increasing the CA:Frc concentration.

The CA:Glc DES was highly viscous, so the solubility test of quercetin in those aqueous solutions could be performed only with the 25 and $50 \%$ aqueous solution. Fig. $1 \mathrm{~d}$ shows the quercetin solubility in the CA:Glc aqueous solutions. At all applied temperatures, the quercetin solubility in all tested CA:Glc aqueous solutions was almost insignificant. The solubility of quercetin in the $75 \%$ CA:Glc aqueous solutions was $0.2,0.3$ and $0.3 \mathrm{mg} / \mathrm{ml}$ at 25,50 and $75{ }^{\circ} \mathrm{C}$, respectively. This eutectic mixture did not dissolve quercetin. Also, the quercetin solubility test with the lecithin-based DESs was impossible due to their viscosity.

\section{Extraction of quercetin from waste onion tunic}

Solvents, such as methanol and ethanol, are commonly used for the extraction of biologically active substances from plant materials. In order to find the most suitable solvent for the selective extraction of quercetin from waste onion tunic, methanol, ethanol and $\mathrm{ChCl:U}$ were tested and their extraction efficiencies were compared (Figure 2). Among the tested DESs, ChCl:U was selected for the quercetin extraction because of its low viscosity and good dissolution capability.

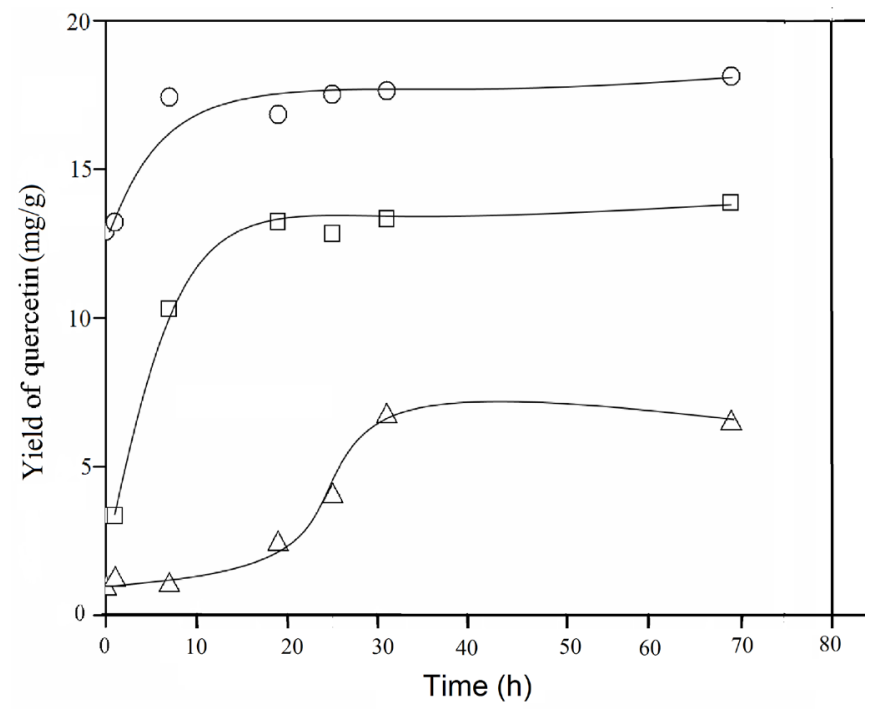

Figure 2. Variations of the yield of quercetin extracted from waste onion tunic by ethanol, methanol and $\mathrm{ChCl:U}$ with the progress of extraction (methanol - $\square$, ethanol - $\circ$ and $\mathrm{ChCl:U}-\triangle$ )

When ethanol was used for the flavonols extraction, the concentrations of quercetin and quercetin-4'-Omonoglucoside of 17 and $9 \mathrm{mg} / \mathrm{g}$ dry material, respectively, were reached after $8.3 \mathrm{~h}$, and they remained constant afterwards. With methanol, the extracted quercetin and quercetin-4'-O-monoglucoside concentrations increased until they reached their maximum of 13 and $7 \mathrm{mg} / \mathrm{g}$ dry material, respectively, after about 16.7 h. The concentrations of extracted quercetin obtained 
with ChCl:U was initially very low, but rose gradually after $12 \mathrm{~h}$, reaching its maximum of $6 \mathrm{mg} / \mathrm{g}$ dry material, while the maximum concentration of quercetin-4'O-monoglucoside of $12 \mathrm{mg} / \mathrm{g}$ dry material was achieved after $30 \mathrm{~h}$ and remained constant until the end of the experiment. Although these extractions were relatively long, these results have shown that the extraction with aqueous ChCl:U solutions can be successfully used to extract polyphenols under mild conditions. Many extractions of polyphenols (quercetin) were reported in the literature, but higher yields of phenolic compounds were obtained only by ultrasound-assisted and supercritical extractions. For instance, Nam et al. [21] applied ChCl:G (1:1) and CA:Glc (1:1) for the ultrasound-assisted extraction of quercetin, kaempferol, and isorhamnetin glycosides from dried Flos sophorae. Only de los Ángeles Fernández et al. [22] used lactic acid:glucose (5:1), CA:Glc (1:1) and CA:Frc (1:1) for the ultrasound assisted extraction of phenolic compounds from by-products of the onion seed production besides by-products of olive oil, tomato and pear canning industries. The quercetin yield from onion seeds was $2.06 \pm 0.23 \mu \mathrm{g} / \mathrm{g}$ dry by-product.
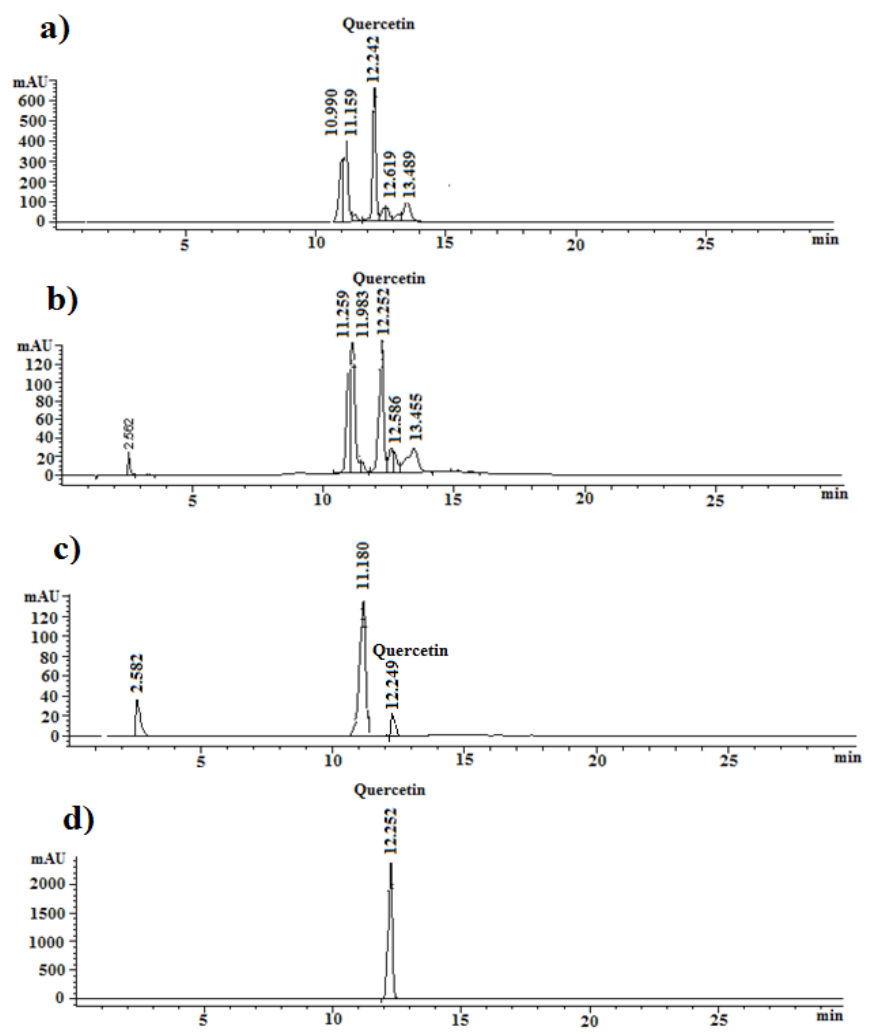

Figure 3. HPLC chromatograms of methanol (a), ethanol (b) and $\mathrm{ChCl:U}$ (c) extracts of waste onion tunic and the standard solution of quercetin (d)

The application of subcritical water extraction of quercetin from onion tunic provided a maximum yield of quercetin (16.29 $\pm 0.75 \mathrm{mg} / \mathrm{g}$ onion tunic) at $165^{\circ} \mathrm{C}$ and $15 \mathrm{~min}$ [23]. Even though the application of subcritical water extraction provided a higher quercetin yield than the extraction with aqueous $\mathrm{ChCl}: \cup$ solutions, the overall processing costs would be much higher. HPLC chromatograms of the methanol, ethanol and $\mathrm{ChCl:U}$ extracts from waste onion tunic are provided in Figure 3a-c. Although conventional solvents like ethanol and methanol extracted a large amount of quercetin, the quercetin extracted with $\mathrm{ChCl}: U$ was less impure, as shown by the HPLC analysis. Therefore, for the selective extraction of pure quercetin, the use of $\mathrm{ChCl}: U$ may be highly recommended.

\section{Conclusions}

Various deep eutectic solvents were mixed with water to enhance the solubility of quercetin at the temperature range of $25-75^{\circ} \mathrm{C}$. In pure $\mathrm{ChCl}: \mathrm{G}$ at $75^{\circ} \mathrm{C}$, the solubility of quercetin had a maximum value of $2.8 \mathrm{mg} / \mathrm{ml}$. The solubility of quercetin in pure $\mathrm{ChCl}: U$ at the temperatures of 25,50 and $75^{\circ} \mathrm{C}$ was in range from 2.5 to $2.7 \mathrm{mg} / \mathrm{ml}$, so the temperature of $25{ }^{\circ} \mathrm{C}$ was selected as the most optimal. Instead of the pure citric acid-based DESs, which were highly viscous and not suitable for the extraction of quercetin, their aqueous solutions were applied. With increasing the concentration of CA:Frc in the aqueous solution at $75{ }^{\circ} \mathrm{C}$, the solubility of quercetin increased almost linearly, reaching the maximum value of $2.16 \mathrm{mg} /$ $\mathrm{ml}$ in the $75 \%$ solution, while CA:Glc was the least efficient. The lecithin-based DESs were also unsuitable for the extraction of quercetin. The quercetin extraction from waste onion tunic with ethanol, methanol and $\mathrm{ChCl:U}$ at $30{ }^{\circ} \mathrm{C}$ showed that their efficiency decreased in the following order: ethanol > methanol > ChCl:U. However, quercetin extracted with $\mathrm{ChCl}: \mathrm{U}$ was most pure, so the use of $\mathrm{ChCl}: U$ was highly recommended for the selective extraction of quercetin.

\section{Acknowledgements}

This work has been funded by the Ministry of Education, Science and Technological Development of the Republic of Serbia (Project III 45001). It is also part of the Project $0-14-18$ of the SASA Branch in Niš (Development, modeling and optimization of biodiesel production from nonedible and waste feedstocks), Serbia.

\section{References}

[1] M. Faggian, S. Sut, B. Perissutti, V. Baldan, I. Grabnar, S. Dall'Acqua, Natural deep eutectic solvents (NADES) as a tool for bioavailability improvement: pharmacokinetics of rutin dissolved in proline/glycine after oral administration in rats: possible application in nutraceuticals, Molecules 21 (2016) 1531-1541.

[2] G. S. Kelly, Quercetin, Monograph, Alternative Medicine Review 16 (2011) 172-194.

[3] R. S. Razmara, A. Daneshfar, R. Sahraei, Solubility of quercetin in water + methanol and water + ethanol from (292.8 to 333.8) K, Journal of Chemical \& Engineering Data 55 (2010) 3934-3936.

[4] L. Dong, M. Liu, A. Chen, Y. Wang, D. Sun, Solubilities 
of quercetin in three $\beta$-cyclodextrin derivative solutions at different temperatures, Journal of Molecular Liquids 177 (2013) 204-208.

[5] H. Chen, Y. Yao, Phytoglycogen improves the water solubility and Caco-2 monolayer permeation of quercetin, Food Chemistry 221 (2017) 248-257.

[6] D. Z. Troter, Z. B. Todorović, D. R. Đokić-Stojanović, B. S. Đordević, V. M. Todorović, S. S. Konstantinović, V. B. Veljković, The physico-chemical and thermodynamic properties of the choline chloride-based deep eutectic solvents, Journal of the Serbian Chemical Society 82 (2017) 1039-1052.

[7] D. Z. Troter, Z. B. Todorović, D. R. Đokić-Stojanović, O. S. Stamenković, V. B. Veljković, Application of ionic liquids and deep eutectic solvents in biodiesel production: A review, Renewable and Sustainable Energy Reviews 61 (2016) 61, 473-500.

[8] Troter D. Z. Troter, Z. B. Todorović, D. R. Đokić-Stojanović, Lj. M. Veselinović, M. V. Zdujić, V. B. Veljković, Choline chloride-based deep eutectic solvents in $\mathrm{CaO}-$ catalyzed ethanolysis of expired sunflower oil, Journal of Molecular Liquids 266 (2018) 266, 557-567.

[9] Y. Dai, J. van Spronsen, G.-J. Witkamp, R. Verpoorte, Y. H. Choi, Ionic liquids and deep eutectic solvents in natural products research: mixtures of solids as extraction solvents, Journal of Natural Products 76 (2013) 21622173

[10] Y. Dai, J. van Spronsen, G.-J. Witkamp, R. Verpoorte, Y. $\mathrm{H}$. Choi, Natural deep eutectic solvents as new potential media for green technology, Analytica Chimica Acta 766 (2013) 766, 61-68.

[11] Y. Dai, J., G.-J. Witkamp, R. Verpoorte, Y. H. Choi, Tailoring properties of natural deep eutectic solvents with water to facilitate their applications, Food Chemistry 187 (2015) 14-19.

[12] Y. H. Choi, J. van Spronsen, Y. Dai, M. Verberne, F. Hollmann, I. W. C. E. Arends, G.-J. Witkamp, R. Verpoorte, Are natural deep eutectic solvents the missing link in understanding cellular metabolism and physiology?, Plant Physiology 156 (2011) 156 1701-1705.

[13] M. C. Bubalo, N. Ćurko, M. Tomašević, K. Kovačević Ganić, I. Radojčić Redovniković, Green extraction of grape skin phenolics by using deep eutectic solvents, Food Chemistry 200 (2016) 159-166.

[14] A. García, E. Rodríguez-Juan, G. Rodríguez-Gutiérrez, J. J. Rios, J. Fernández-Bolaños, Extraction of phenolic compounds from virgin olive oil by deep eutectic solvents (DESs), Food Chemistry 197 (2016) 554-561.

[15] T. Krížek, M. Bursová, R. Horsley, M. Kuchař, P. Tůma, R. Čabala, T. Hložek, Menthol-based hydrophobic deep eutectic solvents: Towards greener and efficient extraction of phytocannabinoids, Journal of Cleaner Production 193 (2018) 193, 391-396.

[16] Z. F. Wei, X. Q. Wang, X. Peng, W. Wang, C.-J. Zhao, Y. G. Zu, Y.-J. Fu, Fast and green extraction and separation of main bioactive flavonoids from Radix Scutellariae, Industrial Crops and Products 63 (2015a) 175-181.

[17] Z. Wei, X. Qi, T. Li, M. Luo, W. Wang, Y. Zu, Y. Fu, Application of natural deep eutectic solvents for extraction and determination of phenolics in Cajanus cajan leaves by ultra performance liquid chromatography, Separation and Purification Technology 149 (2015b) 237-244.

[18] K. Xu, Y. Wang, Y. Huang, N. Li, Q. Wen, A green deep eutectic solvent-based aqueous two-phase system for protein extracting, Analytica Chimica Acta 864 (2015) 9-20.

[19] H. Zhang, B. Tang, K. H. Row, A green deep eutectic solvent-based ultrasound assisted method to extract astaxanthin from shrimp byproducts, Analytical Letters 47 (2014) 742-749.

[20] D. Z. Troter, M. Z. Zlatković, D. R. Đokić-Stojanović, S. S. Konstantinović, Z. B. Todorović, Citric acid-based deep eutectic solvents: Physical properties and their use as cosolvents in sulphuric acid-catalysed ethanolysis of oleic acid, Advanced technologies (2016) 53-65.

[21] M. W. Nam, J. Zhao, M. S. Lee, J. H. Jeong, J. Lee, Enhanced extraction of bioactive natural products using tailor-made deep eutectic solvents: application to flavonoid extraction from Flos sophorae, Green Chemistry 17 (2014) 1-11.

[22] M. de los Ángeles Fernández, M. Espino, F. J. V. Gomez, M. F. Silva, Novel approaches mediated by tailor-made green solvents for the extraction of phenolic compounds from agro-food industrial by-products, Food Chemistry 239 (2018) 671-678.

[23] M.-J. Ko, C.-I. Cheigh, S.-W. Cho, M.-S. Chung, Subcritical water extraction of flavonol quercetin from onion skin, Journal of Food Engineering 102 (2011) 327-333. 
Izvod

\section{EKSTRAKCIJA KVERCETINA IZ OTPADNE LJUSPE CRNOG LUKA (Allium Cepa L.) VODENIM RASTVORIMA RAZLIČITIH EUTEKTIČKIH RASTVARAČA}

Biljana S. Đorđević, Zoran B. Todorović, Dragan Z. Troter, Ljiljana P. Stanojević, Vlada B. Veljković

Univerzitet u Nišu, Tehnološki fakultet, Leskovac, Srbija

U cilju pronalaska najefikasnijeg prirodnog rastvarača za ekstrakciju kvercetina, njegova rastvorljivost je testirana u odabranim eutektičkim rastvaračima (DESs), kao što su holin hlorid:urea (ChCl:U), holin hlorid:glicerol (ChCl:G), limunska kiselina:D-glukoza (CA:Glc), limunska kiselina:D-fruktoza (CA:Frc), lecitin:urea (Lec:U) i lecitin:glicerol (Lec:G), kao i u njihovim vodenim rastvorima, u temperaturnom opsegu od $6-75^{\circ} \mathrm{C}$. Kvercetin se najbolje rastvorio u CA:Frc, a zatim u ChCl:U i ChCl:G, dok je CA:Glc bio najmanje efikasan. DES na bazi lecitina sa ureom i glicerolom nije rastvorio kvercetin. Najoptimalniji DES (ChCl:urea) primenjen je u ekstrakciji kvercetina iz otpadne ljuspe crnog luka (Allium cepa L.), a njegova efikasnost je upoređena sa metanolom i etanolom. Najveća količina kvercetina je ekstrahovana etanolom, pa metanolom a najmanja sa $\mathrm{ChCl} U$, ali kvercetin koji je ekstrahovan ovim DES-om sadržao je najmanju količinu nečistoća. Zbog toga se ChCl:U preporučuje za selektivnu ekstrakciju kvercetina.
(ORIGINALNI NAUČNI RAD)

UDK 66.061:547.972.3:582.573.16

Ključne reči: eutektički rastvarač, ekstrakcija, kvercetin, holin hlorid, limunska kiselina, lecitin 